\title{
İlkokul 2. Sınıf Öğrencilerinin Okuduğunu Anlama Becerilerinin Cinsiyet ve Yaşa Göre İncelenmesi
}

\begin{abstract}
Esra CERAN ${ }^{*}$ Miray OĞUZGİRAY YILDIZ** İlke ÖZDEMİR ${ }^{* * *}$
Öz

Bu çalışmanın amacı, 2013-2014 Eğitim-Öğretim yıll, 2. döneminde bulunan ilkokul 2. sınıf öğrencilerinin Türkçe dersindeki okuduğunu anlama başarılarının cinsiyet ve yaşa göre incelenmesidir. Araştırmanın çalı̧̧ma grubunu, İstanbul ili Avrupa yakasında bulunan Cemal Artüz ve Günebakan İlkokullarından 2. Sınıf düzeyinde 156 öğrenci oluşturmuştur. Bu çalışma tekil modeli ile yapılmış betimsel bir çalışmadır. Araştırmada veri toplama aracı olarak Ceran, Oğuzgiray ve Özdemir(2014) tarafından geliştirilen Türkçe dersi 2. Sınıf Okuduğunu Anlama Başarı Testi kullanılmıştır. Toplanan verilerin analizinde birbirinden bağımsız yaş gruplarının Türkçe dersi 2. Sınıf Okuduğunu Anlama Başarı Testi başarı ortalamaları arasında fark olup olmadığını test etmek amacıyla KruskalWallis analizi, başarının cinsiyete göre değişip değişmediğini anlamak amacıyla ise Mann-Whitney $\mathrm{U}$ testi yapılmışır. Analiz sonuçları, başarı testi uygulanan çocukların yaş gruplarına göre incelendiğinde, 86-92 ay olan çocukların lehine anlamlı bir fark olduğu tespit edilmiştir. Cinsiyet değişkenine göre yapılan analizlerde ise kızların lehine anlamlı bir fark olduğu tespit edilmiştir.
\end{abstract}

Anahtar Kelimeler: Okuma, Okuduğunu anlama, Türkçe dersi.

\section{Investigation Elementary 2.Grades Students Reading Abi- lity of Comprehension according to Gender And Age Vari- able}

\begin{abstract}
The aim of this study is to analyze reading comprehension skills of 2. grade students in Turkish lesson according to sex and age mobility. The data was collected during the spring semester of 20132014 of Cemal Artüz Primary School and Günebakan Primary School in İstanbul from European side. The participants were 156 students in second grade. This study was conducted with qualitative research methods. Research data was collected through questionnaires developed by Oguzgiray, Özdemir and Ceran (2014). In data analysis, Kruskal-Wallis and Mann-Whitney U tests were employed. According to data analysis there is an important significance among age groups, in favor of 86-92 months child. Apart from this, comparisons of gender variable showed that girls had higher scores in comprehension level.
\end{abstract}

Keywords: Reading, Reading comprehension, Turkish lesson..

\footnotetext{
* Arş. Gör., İstanbul Üniversitesi, esraakgulceran@gmail.com

** MEB, Günebakan İlkokulu, Sınıf Öğretmeni, mirayoguzgiray@gmail.com

*** MEB, İMKB Şişli Halk Eğitim Merkezi, Sınıf Öğretmeni, ilkezdmr@gmail.com
} 


\section{GİRIŞ}

Bu bölümde araştırmanın problem durumuna, problem cümlesine, araştırmanın amacına, varsayımlarına, kapsamına, sinırlılıklarına ve tanımlarına yer verilmiştir.

\subsection{Problem Durumu}

Türkiye Cumhuriyeti tarihinde ilk kez 12 yıllık zorunlu eğitimin uygulanmaya başlandığı 2012-2013 eğitim-öğretim programındaki değişim en çok ilkokul öğrencilerini etkilemiştir. 4+4+4 eğitim sistemiyle pek çok değişiklik programa eklenmiştir. Bu çerçevede, okuma yazmaya hazırlık süreci 14 haftaya çıkarıldı, öğrencilerin okula başlama yaşı 60 aya düşürüldü, haftalık ders çizelgelerinde Türkçe, Serbest Etkinlikler, Görsel Sanatlar ve Müzik dersi birer saat eksiltildi, Matematik dersinin ders saati ise bir saat arttırıldı. Serbest Etkinliklerin zorunluluğu kaldırıldı ve velilerin isteği doğrultusunda okul yönetiminin kararına bırakıldı. Ek olarak Beden Eğitimi dersi, Oyun ve Fiziki Etkinlikler dersine dönüştürülerek ders saati sayısı 2'den 5'e çıkarıldı. 1. Sınıfların zorunlu ders saati sayısı, geçen yıla göre 1 saat artırılarak 26 saat oldu. Toplam ders saati ise değişmedi. Bu kapsamda, ilkokul ve ortaokulların kademeli olarak binaları ayrılmaya çalışılıyor. 5 yıl olan ilkokul kısmı ise, 4 yıla düşürüldü.

21 Temmuz 2012'de resmi gazetede yayımlanan yönetmelik degisikligiyle 4+4+4 eğitim sistemi kesinleşmiş oldu. Yönetmelik şu şekilde değiştirilmiştir: "İlkokulların birinci sınıfına, kayıtların yapıldığı yılın Eylül ayı sonu itibarıyla 66 ayını dolduran çocukların kaydı yapılır. Gelişim yönünden ilkokula hazır olduğu anlaşılan 60-66 ay arası çocuklardan, velisinin yazılı isteği bulunanlar da ilkokul birinci sinıfa kaydedilir. Yaşça kayıt hakkını elde eden, ancak bedenen veya zihnen yeterince gelişmemiş olup okula uyum sağlayamayan 66 ay ve üzeri çocuklar da kasım ayı sonuna kadar sağlık kurumlarından verilen bedenen veya zihnen gelişmemiş tıbbi tanılı rapor üzerine okul öncesi eğitime yönlendirilebilir veya kayıtları bir yıl ertelenebilir." şeklinde açıklamalar yapıldı (MEB, 2012).

Okula başlama yaşının sadece 3 ay geriye çekildiği sıklıkla vurgulansa da, bu yaş dönemindeki çocuklar için 1 ay bile gelişimsel anlamda önemli bir farktır (ERG, 2013). 60- 66 ay yaş grubundaki çocukların, daha fazla fiziksel eksiklik gösterdikleri, kalem tutmakta zorlandıkları, okul kültürüne ilişkin davranış ve bilince sahip olamadıkları, diğer yaş gruplarındaki 1. Sınıf öğrencilerine göre daha yavaş ilerledikleri ve geride kaldıkları görülmüştür (Egitim-Bir-Sen, 2013).

4+4+4 eğitim öğretim sisteminin getirdiği tüm değişiklikler, ilkokulda en çok 2012- 2013 eğitim öğretim yılında 1. sınıfa başlayan öğrencileri etkilemiştir. Programda kademeli bir geçiş uygulanmaya çalışılmıştır. Her seviyedeki öğrenci aynı anda değişime tabi tutulmamış, onun yerine 1 . Sınıftan başlamak üzere kademeli bir geçiş söz konusu olmuştur.

İlkokul birinci sınıf, öğrencinin okuma ve okuduğunu anlama becerilerini edinmesi gereken ilk yer olduğu için eğitim öğretim sürecinde kritik bir öneme sahiptir. Bu nedenle bir temel eğitim kurumu olan ilkokulda birinci sınıf, okuma anlama becerilerinin kazandırılması noktasında en önemli sınıf olarak görülmektedir. Birinci sınıfta okuma yazmayla başlayan süreç okuma anlama becerilerinin kazandırılmasiyla devam eder.

İlk çağlardan günümüze dek en etkili bilgi edinme ve yayma yolu olarak görülen yöntemlerden birisi okumadır (Güneş, 2000). Çağdaş toplumlarda öğrenme, daha çok metin okuma yoluyla öğrenme şeklinde gerçekleşir (Savaş, 2006).

Okuma ve anlama becerileri öğrenme için önemli ve gerekli beceriler olduğu için okuma ve anlama ile ilgili becerilerin okulda öğretilmesi gerekmektedir (Şengül \& Yalçın, 2004). Birinci sınıf, öğrencinin okuma ve okuduğunu anlama becerilerini edinmesi gereken ilk yer olduğu için kritik bir öneme sahiptir. Bu nedenle bir temel eğitim kurumu olan ilkokulda 
birinci sınıf, okuma anlama becerilerinin kazandırılması noktasında en önemli sınıf olarak görülmektedir. Birinci sınıfta okuma yazmayla başlayan süreç okuma anlama becerilerinin kazandırılmasıyla devam eder. Öz \& Çelik(2007)'e göre eğitimin tüm kademelerinde yaşanan başarısızlığın temelinde çoğu zaman okuma, anlama ve ifade becerileri bulunmaktadır. Bunun nedenlerinden biri de okuma yazma alışkanlıklarının kazandırılmamış olmasidir.

Okuma anlama becerisi öncelikle mekanik okuma süreci ile başlar. Kavcar, Oğuzkan \& Sever (1997, s. 41) okumayı, 'bir yazıyı, sözcükleri, cümleleri, noktalama işaretleri ve öteki ögeleriyle görme, algılama ve kavrama süreci' olarak değerlendirmektedir. Okumayı, zihinsel süreçler açısından tanımlamaktadırlar. Ona göre okuma, bilişsel davranışlar ve psikomotor becerilerin ortak çalışmasıyla, yazılı sembollerden anlam çıkarma etkinliğidir. Diğer bir tanimla okuma, basılı veya yazılı metinleri duyu organlarımız vasitasıyla algılayıp bunları anlamlandırıp yorumlama işidir (Gürses, 1996).

Okuma eylemi, görme ve seslendirme yönüyle fizyolojik, kavrama yönüyle psikolojik, anlamlandırma yönüyle de sosyolojik bir süreçtir. Bu bağlamda okuma gelişimi, bireysel ve çevresel farklılıkların yanı sıra, biyolojik farklılıklara bağlı olarak da değişebilir (Kayıran \& Karabay, 2012).

Demirel'e(2000, s.77)'e göre okumanın üç boyutu bulunmaktadir. Bunlardan okumanın fizyolojik boyutuna göre, her sözcüğün zihnimizde kendi biçimiyle ilgili görsel bir imgesi vardır. Göz, sözcüğü görür görmez bu imge ile tanır. Gözün algıladığı sözcük görülen yerin anlamına göre seslendirilir. Okuma sırasında, göz, beyin ve konuşma organları ortaklaşa çalışır. Okumanın psikolojik boyutuna göre, öğrencinin iyi bir okuma düzeyine kavuşmasında psikolojik yapısının da önemi vardır. Zihnin algılama ve düşünmede belli bir düzeye yükselmesi gerekir. Öğrencilerin duygusal olgunluğa kavuşturulması da önemlidir. Okumanın sosyolojik boyutuna göre ise, kişi belli bir kül- tür düzeyinde eğitildiği için, içinde bulunduğu çevrenin varlığı çok önemlidir. Okuma eğitiminin gelişmesinde aile bireylerinin etkisi çok önemlidir.

Smith ve Dechant(1961) okumayı tanımlarken iki noktaya vurgu yapmışlardır. Bunlar tanıma ve algılamadır. Tanıma; harflerin, kelimelerin tanınması olup duyusal bir etkinliktir. Tanıma etkinliğini, materyalin beyinde algılanması izler. Algilama sirasinda bu materyal hem örgütlenir, hem anlamlandırılır, hem de bunların eski bilgilerle bağlantısı kurulur (Akt.: Dökmen, 1994, s.13).

Okula yeni başlayan öğrencilerin çok büyük bir kısmı okula başladıklarında okuma-yazma becerilerine sahip değillerdir. Bu nedenle ilköğretim okullarının ilk 3 yıllık süreçlerinde öğrencilere okuma yazma becerisi kazandırmaktır (Güneş, 2000). İlk üç yıllık süreçte okuma ve yazma becerisini kazanmış olduğunu kabul ettiğimiz ilköğretim öğrencilerinin bundan sonraki beş yıllık süreçte Türkçe derslerinde konuşma, yazma, okuma, dinleme ve dil becerilerini geliştirmeyi hedeflendiği belirtilmektedir (Cemiloğlu, 2001).

Örgün ve yaygın eğitime devam eden öğrencilere, eğitimleri süresince çeşitli bilgiler verilmekte, ancak anlama becerilerindeki eksiklikler nedeniyle bu bilgilerden yeterince yararlanamadıkları ve bu bilgileri hayata geçiremedikleri; bu olumsuz durumun ilkokuldan üniversiteye kadar, hatta lisansüstü eğitim düzeyinde bile yaygın bir şekilde var olduğu görülmektedir (Güneş, 1995; Akt: Şengül \& Yalçın, 2004).

Okuma ve okuduğunu anlama becerilerinin gelişmesi için öğrencilerin belirli bir hazırbulunuşluluk seviyesinde olmaları gerekmektedir. Çünkü öğrencilerin belirli bir gelişim düzeyinde olmaları öğrenmenin etkililiğinde önemli rol oynamaktadır. Ancak Milli Eğitim Bakanlığı, 4+4+4 eğitim sistemiyle, yaşları eşit olmayan 60 ve 84 aylık çocukların aynı sınıfta ilkokula başlamasıyla hazırbulunuşluluk göz ardı edilmiştir. Türkiye'de eğitim-öğretimin Türk Milli Eğitiminin temel ilkelerinden olan fırsat eşitliğine göre düzenlenmesi gerekmektedir. Deği- 
şen eğitim-öğretim sistemiyle bunun aksi yönünde değişimler yaşanmıştır. Öğrencinin hayat boyu öğrenmesini etkileyecek olan okuduğunu anlama becerisinin geliştirileceği tek yer olan ilkokullarda tüm öğrencilerin kazanabileceği bir beceri olmalıdır. Geçen yıl 1. sınıfa başlayan öğrenciler 2.sınıfa geldiklerinde tüm derslerdeki başarıları gözlemlendiğinde yaşları farklı olan öğrencilerin başarıları arasında bir fark olduğu gözlemlenmiştir.

\section{2 Çalışmanın Amacı}

$\mathrm{Bu}$ araştırmada 2. sinıf öğrencilerinin okuduğunu anlama becerileri yaş grupları ve cinsiyete göre karşılaştırılması amaçlanmıştır. Bu amaçla aşağıdaki sorulara yanıt aranmıştır:

1. Yaşları $72-78$ ay, $79-85$ ay ve $86-92$ ay olan öğrencilerin Türkçe dersi okuduğunu anlama başarıları arasında istatistiksel açıdan anlamlı bir fark var mıdır?

2. 2.sınıfta okuyan farklı yaşlardaki öğrencilerin Türkçe dersi okuduğunu anlama başarıları cinsiyete göre farklılık göstermekte midir?

\section{YÖNTEM}

\subsection{Araştırmanın Modeli}

$\mathrm{Bu}$ araştırma, tarama modellerinden tekil tarama modeli ile yapılmış betimsel bir çalışmadır. Tarama modelleri; geçmişte veya halen var olan durumu, var olduğu şekli ile betimlemeyi amaçlayan araştırma yaklaşımıdır (Karasar, 2000).

\section{2 Çalışma Grubu}

Araştırmanın çalışma grubunu 2013-2014 Eğitim-Öğretim yılı 2. yarıyılında, İstanbul ilinde ilkokul 2.sınıf öğrenimine devam eden öğrenciler oluşturmuştur. Çalışmanın örneklemini ise, İstanbul'un Avrupa yakasından seçkisiz yolla seçilen 2 ilkokulda öğrenim gören 156 2. Sınıf öğrencisi oluşturmuştur.

\subsection{Veri Toplama Aracı}

Verilerin toplanması amacıyla araştırmacılar tarafından 500 soruluk bir soru havuzu oluşturulmuştur. Ardından bu sonuçlar iki farklı uzmana gösterilerek elenmiştir. Kalan sorular incelenmiş, birbirleriyle ilişkili olan maddelerden fazla olanları çıkarılmıştır. Sonuçta oluşan 2.Sınıf Okuduğunu Anlama Başarı Testi bir dil uzmanına ve bir de eğitim uzmanına gösterilmiştir. Gerekli düzenlemeler yapılmıştır, ardından hazırlanan test bu dersi alıp geçmiş olan 3.sınıf öğrencilerine ve hiç almamış 1.sınıf öğrencilerine uygulanmıştır. Uygulanan testten elde edilen sonuçlara göre her maddenin madde güçlük indeksi ve ayırıcılık gücü bulunmuştur. Ayırıcılık gücü 0.20'nin altında bulunan sorular çıkarılarak test hazırlanmıştır.

Kullanılmasındaki amaç ne olursa olsun, testin kapsam yönünden ölçme konusunun bilgileri yeterli derecede temsil etmesi gerekir. Testin kullanılış amacı programın sağlamlığını, öğretimin etkililiğini veya öğrenme eksiklerinin saptanması ise öğrencilerin başarılarını değerlendirmek, onları uygun biçimde örnekleyecek şekilde seçilmiş daha az sayıda sorudan oluşan bir grubu yoklar. Kapsam geçerliği çalışmalarını yapabilmek için öncelikle o testin ölçeceği bilgi ifadesinin kapsamı belirtilmelidir. Araştırmacı burada okuduğunu anlama becerisini ölçmek istediği için diğer kazanımlardan bağımsız olarak yalnızca öğrencilerin okuduklarını anlayıp anlayamadıklarını ölçmek istemektedir. Yalnızca öğrencilerin bu sınıf düzeyine kadar öğrenmeleri beklenen türlerdeki metinlerde (şiir, masal, hikâye) ve öğrendikleri varsayılan kelimeler kullanılarak test hazırlanmıştır. Bu sayede anlamını bilmediği kelimenin ve ya daha önce görmediği bir türdeki metnin okuduğunu anlama başarısını etkilemesinin önüne geçilmeye çalışılmıştır. Kapsam geçerliğini tayin etmek daha çok uzman kanılarına (subjektif görüşlere) dayanır. Bu amaçla kapsam geçerliğini belirlemek için iki farklı konu alanı uzmanından görüş alınmıştır. Uzmanlar- 
dan bir tanesi soru sayısının azaltılması gerektiğini belirtirken; diğeri ise soruların öğrencilerin okuduğunu anlama becerisini ölçmeye uygun olduğunu belirtmiştir. İlk uzmanın görüşleri göz önünde bulundurularak 22 soru olması öngörülen test, 20 soruya düşürüldü. Daha sonra uygulayıcıların görüşleri alındı. Uygulayıcılardan bir tanesi, test için verilen sürenin yeterli olmadığını vurgularken, diğer 4 uygulayıcı ise sürenin yeterli olduğunu belirtmiştir. Öğrencileri gözlemleyen uygulayıcılar, bir soruda bulunan İngiliz kelimesinin İngiltere'de yaşayanları ifade ettiğini anlayamayan öğrencilerin olduğunu vurgulayarak değiştirilmesi gerektiği konusunda fikir bildirdiler. Bu nedenle öğrencilerin daha kolay anlayabileceği Alman-Almanya kelimeleri getirildi. Görünüş geçerliği için iki farklı uzmandan görüş alındı ve testin uygun olduğu belirtildi. Hazırlanan maddelerin, belirlenen konulara ait soruları içerdiği ve o konuya ait kazanımları ölçmeye yönelik olduğu tespit edildi.

Geliştirilen bu testin, güvenirlik çalışmaları yapmak için 157 2. sinıf öğrencisine uygulama yapıldı. Madde istatistikleri ile yapılan güvenirlik hesaplamaları için en çok kullanılan formüllerden biri Kuder-Richardson-20 formülüdür (Karasar, 2005, s.150). KR-20 değerinde, iç tutarlığ 1 belirlemek için test maddelerinde verilen her doğru cevap içi “1”, her yanlış cevap için " 0 ” puan kodlanmıştır. Bu nedenle, okuduğunu anlama başarı testinin güvenirlik çalışması için KR-20 değeri hesaplanmıştır ve testin Cronbach Alpha katsayısı ,768 olarak bulunmuştur. Standardize edilmiş Cronbach's Alpha ise ,779 olarak bulunmuştur. Testin güvenirlik katsayısı olarak .88 değeri hesaplanmıştır. Bu değerin .70'den büyük olması testin güvenilir olduğu anlamına gelmektedir (Büyüköztürk, 2002, s.171).

Pearson Correlation yapıldığında, testin her bir maddesi ile testin toplamından alınan puanlar arasındaki ilişkiye bakıldığında, tüm maddelerin $>, 05$ düzeyinde anlamlı olduğu görülmüştür. Buna göre testin her bir maddesinin testin geneliyle ilişkili olduğunu söylenebilir.

Faktörlerin daha anlamlı ve yoruma uygun hale gelmeleri için döndürme işlemi uygulanmaktadır. Burada önemli olan faktörlerin neleri temsil ettikleridir. Döndürme işlemi faktörlerin değişkenleri daha iyi temsil edebilmeleri için faktör eksenlerinin hareket ettirilmesidir. Ancak faktör analizinde döndürmeler basit yapıya ulaşmayı garanti etmediği gibi döndürmeden sonra elde edilecek faktör sonuçları, elde edilen ilk faktör sonuçlarından daha anlamsız da olabilmektedir (Tatlıdil, 2002, s.175)

Faktörler, döndürülmüş faktör matrisi ile daha anlamlı hale gelmektedir. Her bir faktörün temsil ettiği değişken grubunu yüksek oranda açılayıp diğer faktörlerin temsil ettikleri değişken gruplarını ise düşük oranda açıklamaları döndürme ile mümkün olabilmektedir. Bunun yanında, döndürme işlemi sonunda değişkenlerin ortak varyansı değişmez. Döndürülmemiş faktör matrisinde birinci faktör en fazla varyansı açılamakta ve birinci faktörden sonuncu faktöre doğru gidildikçe daha az varyans açıklanmaktadır. Ancak döndürülmüş faktör matrisinde her faktör birbirine yakın miktarlarda varyansa katılmaktadır. Faktör matrisini döndürmenin temel amacı, daha basit bir yapı ve teorik olarak daha anlamlı bir faktör matrisi elde etmek için önceki faktörlerin açıkladığı toplam varyansı faktörler arasında yeniden dağıtmaktır. Yani her faktörün, değişkenlerden sadece bazıları için sıfır olmayan yüklere sahip olması gerekir. Böyle bir durum faktörü daha kolay yorumlamaya yardım etmektedir. Ayrıca her bir değişkenin faktörlerden sadece bazılarıyla (tercihen tek bir faktörle) sıfır olmayan bir yüke sahip olması beklenir. Böylece faktörlerin birbirinden farklılaşması sağlanır. 
Tablo 1. Dönüşümlü Faktör Yükleri (Rotated Component Matrix (a))

\begin{tabular}{|c|c|c|c|c|c|c|c|}
\hline & \multicolumn{7}{|c|}{ Component } \\
\hline & 1 & 2 & 3 & 4 & 5 & 6 & 7 \\
\hline Soru1 & ,723 & , 037 & 142 &,- 017 &,- 156 & , 054 & ,049 \\
\hline Soru13 & 681 & ,010 &,- 059 & 130 & 165 & ,098 & 112 \\
\hline Soru2 & 650 & ,084 & 161 &,- 091 & ,048 & ,233 & 175 \\
\hline Soru4 &, 558 & ,369 &,- 214 & 113 & 134 & ,218 &,- 360 \\
\hline Soru20 & ,467 & 294 & ,059 &,- 090 & ,022 &,- 351 & ,035 \\
\hline Soru10 & ,098 & 710 & ,076 &,- 009 &,- 047 & 189 &,- 116 \\
\hline Soru19 &,- 164 & ,675 &,- 201 &,- 063 &,- 071 & ,022 & ,226 \\
\hline Soru9 & 296 & ,569 & ,220 & ,059 &,- 023 & 175 & ,034 \\
\hline Soru12 & 158 &, 563 & ,305 & ,045 & 133 &,- 136 & ,090 \\
\hline Soru17 & ,359 & ,430 & ,083 &,- 205 & 142 &,- 273 &,- 414 \\
\hline Soru14 &,- 012 & ,024 & 844 & 114 & ,026 &,- 030 &,- 011 \\
\hline Soru6 & 161 & 228 & 443 &,- 130 & ,206 & ,424 &,- 357 \\
\hline Soru8 & ,358 & ,319 & ,402 &,- 214 &,- 221 & ,049 &,- 052 \\
\hline Soru5 & ,053 & ,017 & ,073 & 854 &,- 039 &,- 031 &,- 003 \\
\hline Soru15 & 235 & 283 & ,392 &,- 488 & 182 &,- 122 & 101 \\
\hline Soru18 & ,032 & ,096 & ,019 & 093 &,- 839 &,- 003 & ,081 \\
\hline Soru7 & 140 & 200 & ,261 & ,408 & ,438 &,- 060 & , 142 \\
\hline Soru3 & ,241 & 160 &,- 048 &,- 005 &,- 030 & ,744 & ,045 \\
\hline Soru16 & ,326 & 157, &,- 036 & -,012 &,- 001 &,- 015 & 699 \\
\hline Soru11 & ,225 & ,415 & ,143 &,- 156 & ,389 & ,338 & ,419 \\
\hline Faktör1 & Faktör2 & & & Faktör4 & Faktör6 & & \\
\hline $\begin{array}{l}\text { Madde1, Mad- } \\
\text { de2, Madde4, } \\
\text { Madde13, } \\
\text { Madde20 }\end{array}$ & $\begin{array}{l}\text { Madde9, } \\
\text { Madde12, } \\
\text { Madde19 }\end{array}$ & & $\begin{array}{l}\text { de6, } \\
\text { de14 }\end{array}$ & $\begin{array}{l}\text { Madde5, } \\
\text { Madde15 }\end{array}$ & Madde3 & & \\
\hline
\end{tabular}

Ortak varyans; bir değişkenin analizde yer alan diğer değişkenlerle paylaşılan varyans miktarıdır. Analiz sırasında, faktör yük değeri 0,45 ya da daha yüksek olanlar analize alınmış, faktör yük değeri 0,45'in altında bulunan maddeler analizden çıkarılmıştır (Balcı, 1995, s.142143). Ayrica, birden fazla faktörde, 0.10 'dan daha az bir farkla yer alan her hangi bir madde, binişik bir madde olarak değerlendirildiğinden, bu özellikteki maddeler de ölçekten çıkarılmıştır. (Büyüköztürk, 2002, s.118-119) Tablo 1'de görüldüğü üzere; 20 maddeden oluşan deneme ölçeğinde, analizler sonucunda 14 madde kalmış ve 6 boyutlu bir ölçek elde edilmiştir.

Kalan 14 madde ile tekrar faktör analizi yapılmıştır ve Tablo 2' de sonuçları verilmiştir. 
Tablo 2. Dönüşümlü Faktör Yükleri (Rotated Component Matrix (a))

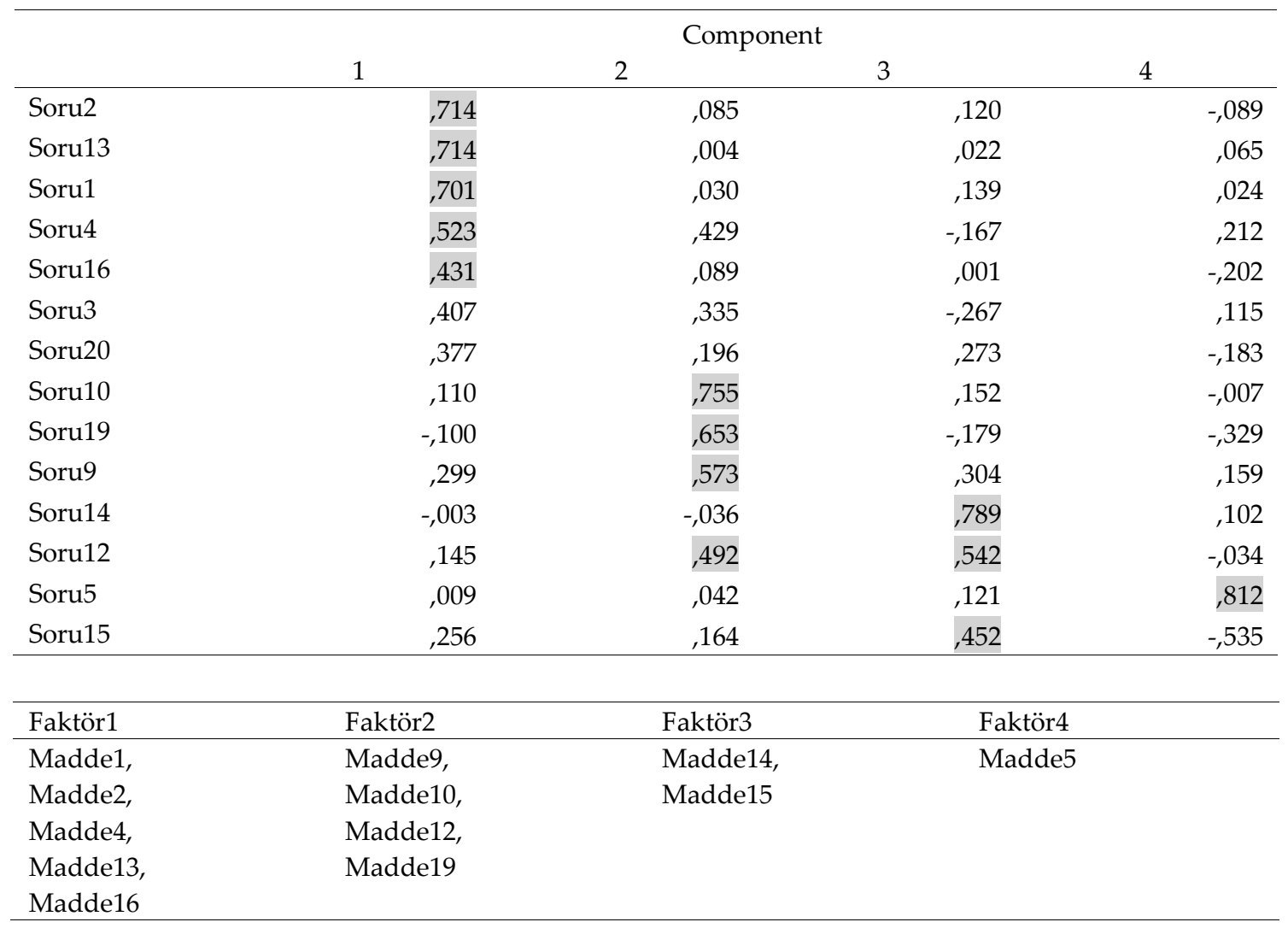

Tablo 2'de görüldüğü üzere; 14 maddeden oluşan deneme ölçeğinde, analizler sonucunda 12 madde kalmış ve 4 boyutlu bir ölçek elde edilmiştir.
Kalan 12 madde ile tekrar faktör analizi yapılmiştır ve Tablo 3'te sonuçları verilmiştir.

Tablo 3. Dönüşümlü Faktör Yükleri (Rotated Component Matrix (a))

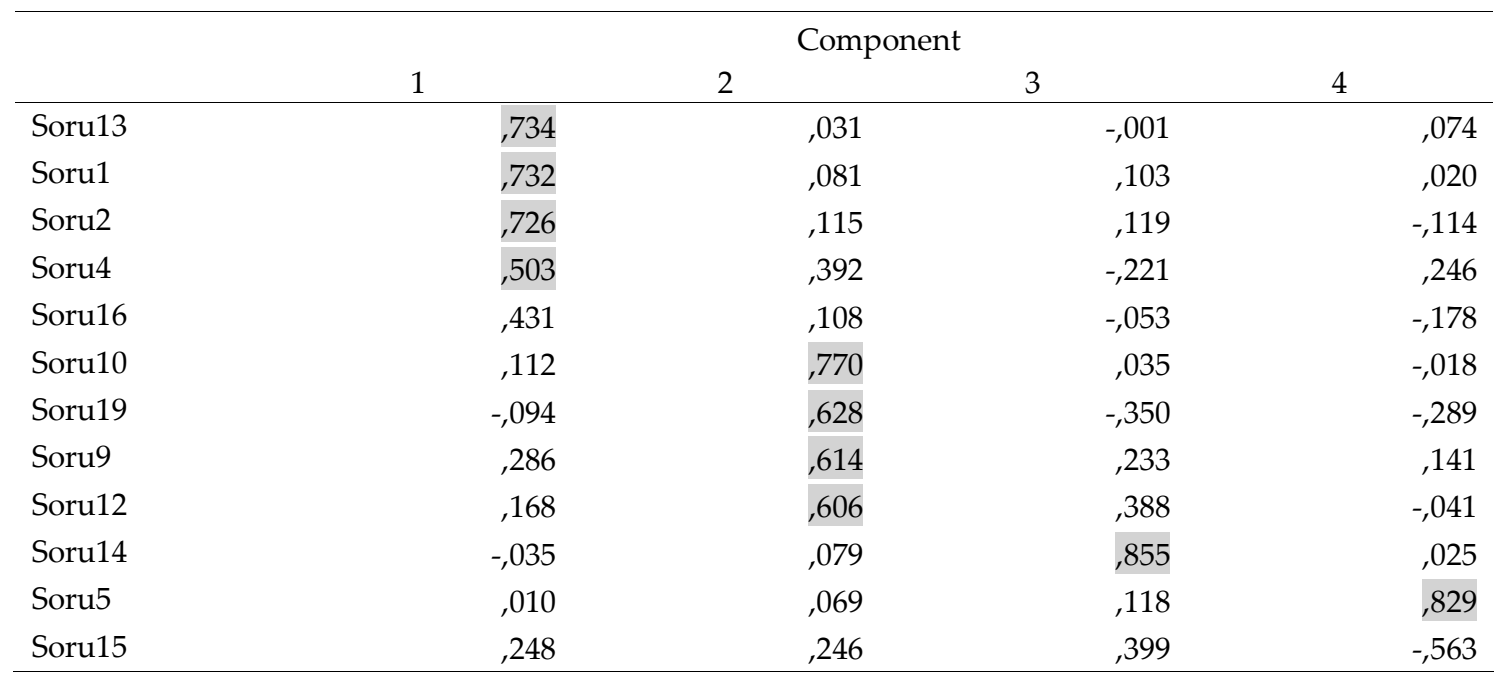




\begin{tabular}{llll}
\hline Faktör1 & Faktör2 & Faktör3 & Faktör4 \\
\hline Madde1, & Madde9, & Madde14 & Madde5 \\
Madde2, & Madde10, & \\
Madde4, & Madde12, Madde19 & & \\
Madde13 & & & \\
\hline
\end{tabular}

Tablo 3'te görüldüğü üzere; 12 maddeden oluşan deneme ölçeğinde, analizler sonucunda 10 madde kalmış ve 4 boyutlu bir ölçek elde edilmiştir.
Kalan 10 madde ile tekrar faktör analizi yapılmıştır ve Tablo 4 'te sonuçları verilmiştir.

Tablo 4. Dönüşümlü Faktör Yükleri (Rotated Component Matrix (a))

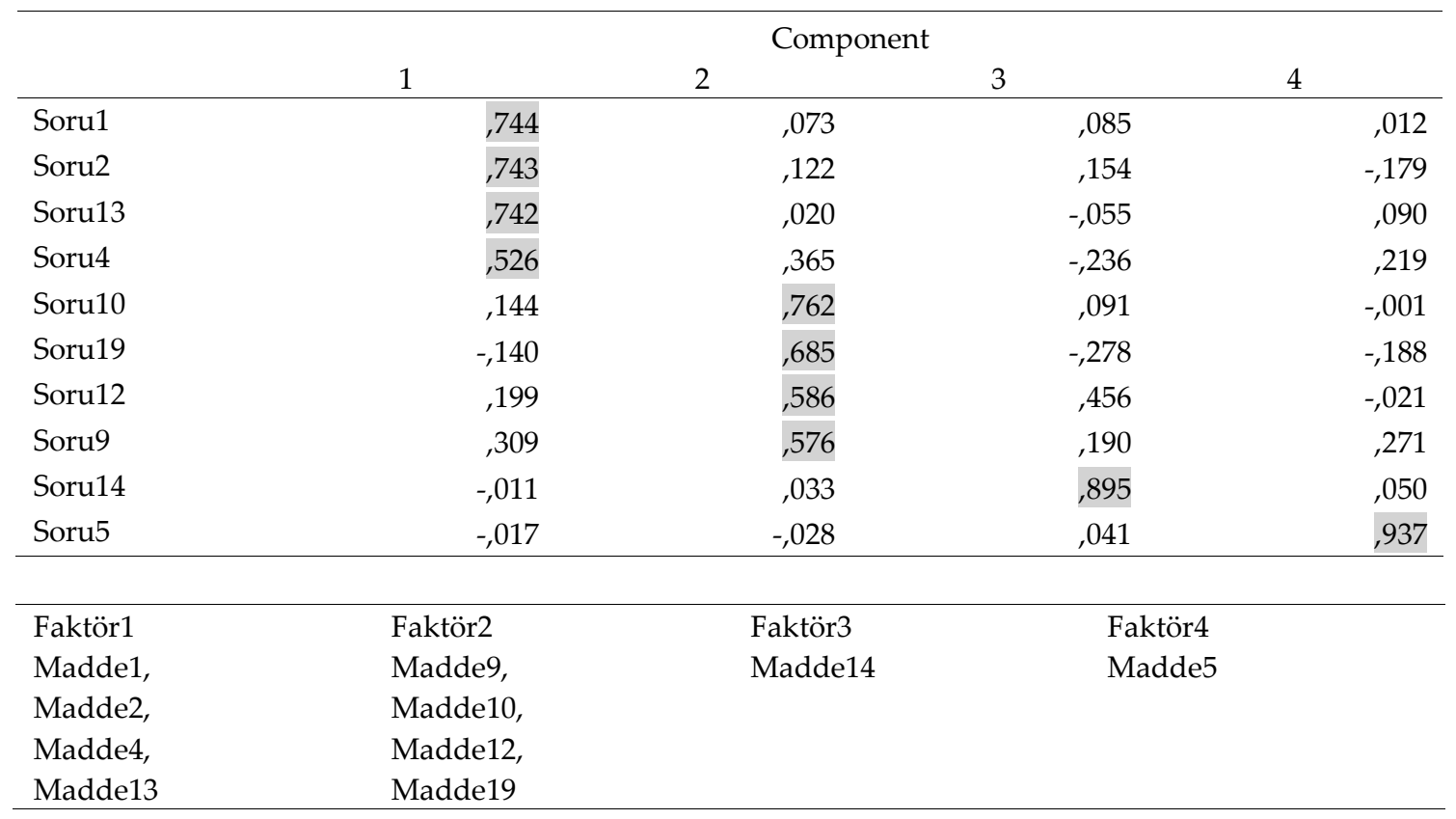

Faktörlerin yorumlanması ve adlandırılması faktör yükleri dikkate alınarak yapılır. Buna göre, değişkenin ortak faktörle olan korelasyonu $\pm 0,30$ 'dan büyükse o değişkenin söz konusu ortak faktörle anlamlı bir ilişki gösterdiği kabul edilmektedir. Bazı araştırmacılara göre bu oran $\pm 0,40$ hatta $\pm 0,50$ olmalıdır. Bir faktörün adlandırılmasında, $\pm 0,30$ ' dan büyük pozitif faktör yükleri dikkate alındığı gibi, negatif faktör ağırlıkları da dikkate alınmalıdır. Söz konusu ortak faktör, pozitif faktör ağırlıkları ile olumlu, negatif faktör ağırlıkları ile olumsuz ilişki gösterecek şekilde yorumlanmalıdır. Böylece faktörlere iki kutuplu olarak bakılabilir (Albayrak,2005, s.124-125). Buna göre adlandirılan faktörlerin başlıkları 2 uzman görüşü alınarak ölçeğin alt boyutları adlandırılır. 
Tablo 5. İletişim Becerilerini Değerlendirme Ölçeğine Ait Değerler

\begin{tabular}{|c|c|c|c|}
\hline & Ölçeğin Alt Boyutları & İlgili Maddeler & $\begin{array}{c}\text { Alt Boyutlarından Alına- } \\
\text { bilecek En Düşük ve En } \\
\text { Yüksek Puanlar }\end{array}$ \\
\hline 1. & $\begin{array}{l}\text { Boyut: Metindeki bilgiye da- } \\
\text { yalı sorular }\end{array}$ & $1,2,4,13$ & $0-40$ \\
\hline 2. & $\begin{array}{l}\text { Boyut: Yoruma dayalı soru- } \\
\text { lar }\end{array}$ & $9,10,1219$ & $0-40$ \\
\hline 3. & $\begin{array}{l}\text { Boyut: Parçadan çıkarımda } \\
\text { bulunmaya dayalı sorular }\end{array}$ & 14 & 10 \\
\hline 4. & $\begin{array}{l}\text { Boyut: Paragraftan anlam } \\
\text { kurmaya dayalı sorular }\end{array}$ & 5 & 10 \\
\hline
\end{tabular}

Tablo 6. İlişkisiz Gruplar T Testi Sonuçları

\begin{tabular}{lcccccc}
\hline Gruplar & $n$ & $X$ & $S s$ & $T$ & $s d$ & $p$ \\
\hline 1. Sinıf & 93 & 12,02 & 3,77 & 3,2 & 153 &, 001 \\
3.Sinıf & 137 & 14,15 & 3,68 & 3,2 & 80,152 &, 002 \\
\hline
\end{tabular}

Test, okuduğunu anlama eğitimi almamış 1 . sınıf öğrencileri ile bu eğitimi almış 3. sınıfın ilk dönemi ikinci haftasındaki öğrencilere uygulanarak iki grubun başarıları karşılaştırılmıştır. Aritmetik ortalamalara bakıldığında 3. sınıf öğrencilerinin Okuduğunu Anlama Testi puanları $(x=14,15), 1$. sinıf öğrencilerinin Okuduğunu Anlama Testi puanlarından $(x=12,02)$ daha yüksektir. $p<, 002$ düzeyinde anlamlı bir fark olduğu görülmüştür. Başka bir ifadeyle, 3. sınıf öğrencileri, 1. sınıf öğrencilerinden daha başarı11 bulunmuştur. Buna göre 2. sinıflar için hazırlanan bu başarı testi, bu konuyu öğrenmemiş 1 . sınıf ve bu konuyu öğrendiği düşünülen 3.sınıf öğrencilerinin bilgilerini ayırt etmede kullanılabilir. Tüm geçerlik ve güvenirlik analizlerinin sonucunda geçerli ve güvenilir bir ölçek geliştirildiği söylenebilir.

\subsection{Verilerin Yorumlanması}

Verilerin toplanmasında sürecinde 2. sınıf öğretmenlerine '2.Sınıf Okuduğunu Anlama Başarı Testi' verilmiş ve uygulamaları sağlanmıştır. Uygulama sürecinde Milli Eğitim Bakanlığı, İstanbul İl Müdürlüğünden testin uygulanması için gerekli izinler alınmıştır. Gruplar oluşturulurken öğrencilerin yaşları dikkate alınmıştır. Her gruba '2.Sınıf Okuduğunu Anlama Başarı Testi' uygulanmıştır ve sonuçları SPSS 20.00 programında analiz edilmiştir.

\subsection{Verilerin Çözümlenmesi}

2.Sınıf öğrencileri, yaşları belirlenerek 3 gruba ayrılmıştır. 1.grup; 72-78, 2.grup;79-85, 3.grup ise 86-92 aylık öğrencilerden oluşmaktadır. Bu üç grup öğrencinin test sonuçları SPSS 20.00 programında analiz edilerek bağımsız $\mathrm{t}$ testi sonuçlarına bakılmıştır.

\subsection{Verilerin Yorumlanması}


Tablo 7. Okuduğunu Anlama Testi Toplam Puanının Yaş Gruplarına Göre Kruskal-Wallis Sonucu

\begin{tabular}{llccccc}
\hline $\begin{array}{l}\text { Öğrencilerin Test } \\
\text { Puanları }\end{array}$ & Gruplar & $n$ & $\bar{x}_{\text {sira }}$ & $x^{2}$ & $s d$ & $p$ \\
\hline & 72-78 Aylık & 63 & 60,29 & & &, 000 \\
& $79-85$ Aylık & 18 & 121,64 & 27,74 & 2 &, 45 \\
& 86-92 Aylık & & & &
\end{tabular}

Analiz sonuçları, başarı testi uygulanan çocukların yaş gruplarına göre 3.gruptaki (86-92 aylık) çocukların lehine anlamlı bir şekilde farklılaştığını göstermektedir. $x^{2}(\mathrm{sd}=2, \mathrm{n}=156)=$ $27.748, .00<.0 .5$ olduğundan bulgu, aynı sınıfta yaş dönemi olarak daha büyük okula başlayan grupta okuduğunu anlama becerilerinin fazla olduğunu gösterir. Grupların sıra ortalamaları dikkate alındığında, en yüksek beceriye 86-92 aylık öğrencilerin sahip olduğu, bunu 79-85 aylık ve 72-78 aylık öğrencilerin takip ettiği görülmektedir.

Tablo 8. Okuduğunu Anlama Testi Toplam Puanının Cinsiyete Bağlı Mann Whitney U Testi Sonucu

\begin{tabular}{lccccc}
\hline Gruplar & $n$ & $\overline{\mathbf{X}}_{S}$ & Stra Toplamı & $U$ & U \\
\hline K1z Öğr. & 71 & 86,78 & 6161,50 & 2429,50 &, 036 \\
Erkek Ö̈̆gr. & 85 & 71,58 & & & \\
\hline
\end{tabular}

Cinsiyet değişkenine göre incelenen gruptan kız ve erkeklerin farklı yaş gruplarına göre “Türkçe Okuduğunu Anlama Testi”nden aldıkları puanların Mann Whitney U-testi sonuçları Tablo 8'de verilmiştir. Buna göre iki farklı grupta yapılan araştırma sonucu kızlar lehine anlamlı farklılık olduğu bulunmuştur. $\mathrm{U}=2429,50 \quad p<.0 .5$ ortalamaları dikkate alınd1ğında, kız öğrencilerin, erkek öğrencilere göre okuduğunu anlama becerilerinin daha yüksek olduğu anlaşılmaktadır.

\section{BULGULAR VE YORUM}

2. Sınıf öğrencilerinin okuduğunu anlama becerilerinin 72-78 ay, 79-85 ay ve 86-92 ay grupları ve cinsiyete göre farklılaşıp farklılaşmadığını araştırmak amacıyla yapılan bu çalışma sonucunda elde edilen bulgulara göre, grupların ortalamaları dikkate alındığında, en yüksek beceriye 86-92 aylık öğrencilerin sahip olduğu, bunu 79-85 aylık ve 72-78 aylık öğrencilerin takip ettiği görülmektedir. Bunun yanında iki farklı cinsiyet grubunda yapılan araştırma sonucu istatistiksel olarak kılar lehine anlamlı farklılık olduğu bulunmuştur.

Alandaki çalışmalar incelendiğinde 60-66 aylık 1.sınıf öğrencilerinin okuma yazma becerilerini kazanmada daha çok zorlandiğı görülmüştür.72-84 ve 66-72 ay yaş grubundaki çocukların okuma-yazma becerilerini kazanma düzeyleri 60-66 ay yaş grubundaki çocuklardan daha yüksektir (Gündüz \& Çalışkan, 2013). Kılıç (2014)' 1 yaptığ 1 araştırma sonucunda, 72 ay ve üzeri öğrencilerin dil becerileri(dinleme, konuşma, okuma, yazma) düzeyinin, 66-72 aylık öğrencilere göre; 66-72 aylık öğrencilerin dil becerileri düzeyinin de 60-66 aylık öğrencilere göre daha yüksek olduğu görülmüştür. Dil becerilerinin okuduğunu anlama üzerindeki etkisi göz önünde bulundurulduğunda 2. sınıfa geçen öğrencilerde bu farkın kapanmamış olması eğitim öğretim süreci için önemli bir bulgudur. 60-66 aylık gruplarda daha yoğun gözlemlenen bu güçlükler nedeniyle öğrencinin okula karşı olumsuz tutum geliştirebileceği ve olumsuz bir akademik benliğe sahip olabileceği 
düşünülebilir. Olumsuz akademik benlik algisı, beraberinde yetersizlik ve başarısızlık duygusunu getirerek öğrencinin ikinci sınıfta temel okuma ve okuduğunu anlama becerisinde negatif yönde etki yarattığı söylenebilir. Öğrencilerin temel okuma ve akıcı okumada yaşadıkları güçlükler, öğrencilerin okuduğunu anlama durumlarını etkilemiştir. Öğrencilerin hikâye edici metinlerde okuduğunu anlama düzeyleri incelendiğinde yetersiz okuyucu düzeyinde oldukları görülmüştür(Sidekli, 2010). Bu da yapılan çalışmada elde edilen sonucu temellendirmede önemli bir bulgudur.

\section{TARTIŞMA, SONUÇ VE ÖNERILER}

Yapılan çalışmalar sonucunda, ilköğretim 2 . sınıfta okuduğunu anlama başarısı yaş gruplarına göre farklılık gösterdiği görülmüştür. Bu farklılık incelendiğinde, yaş grubu büyük olan 86-92 aylık, yani 3. grup öğrencilerinin okuduğunu anlama konusunda daha başarılı olduğu görülmüştür. 2 yıldır aynı sınıfta aynı eğitimi alan öğrencilerin test sonuçlarının bu denli farklı çıkmasının nedeni, öğrencilerin hazırbulunuşluk seviyelerindeki farklılıktan kaynaklandığı düşünülebilir.

Araştırmada cinsiyete göre yapılan değerlendirmede kız öğrencilerin okuduğunu anlama testi puanlarının erkeklere oranla istatistiksel açıdan daha anlamlı görülmüştür. Çiftçi ve Temizyürek(2008)'in yaptığı araştırmalarda da cinsiyete göre yapılan değerlendirmede $\mathrm{kız}$ öğrencilerin erkek öğrencilere oranla daha başarılı oldukları tespit edilmiştir. Kızların başarı ortalaması \% 87,70 iken; erkeklerin başar1 ortalaması ise \% 83,21 seklindedir. Bu durum kız çocuklarının daha çok evcilik vb. isimlerle adlandırılan iletişim ve empati gerektiren oyunları oynamaları, erkek çocuklarının ise güç ve mücadele gerektiren oyunları oynamaları ile ilgili olduğu düşünülebilir. Kız çocuklarının erkek çocuklarına göre daha dışa dönük olmalarının da anlama ve anlamlandırma etkinlikle- rindeki başarıları ile ilişkileri araştırılabilir. $\mathrm{Bu}$ bulgulardan yola çıkarak araştırma sonucunda k1z öğrencilerin erkek öğrencilere, $79-85$ ve 8292 aylıkların 72-77aylıklara göre okuduğunu anlama becerilerinin istatistiksel açıdan pozitif yönde anlamlı olduğu söylenebilir.

\section{1 Öneriler}

Araştırma kapsamında ulaşılan sonuçlara ilişkin öneriler aşağıda uygulayıcılar ve araştırmacılar için öneriler olmak üzere iki alt başlık halinde verilmiştir.

\subsection{Uygulayıcılara Öneriler}

1. Araştırmadan elde edilen bulguya göre, yaşları daha küçük olan öğrenciler, yaşları daha büyük olan öğrencilere göre okuduğunu anlama testinden daha düşük puanlar almışlardır.

2. 2. Sınıf öğretmenleri, öğrencilere bu araştırma kapsamında geliştirilen Okuduğunu Anlama Testini uygulayarak öğrencilerinin anlama düzeylerini belirleyebilirler.

3. Aynı sınıf düzeyinde eğitim alan öğrenciler, ilkokul düzeyinde farklı bilişsel süreçlere sahip olabilmektedirler. Bu araştırmada, öğrencilerin okuduğunu anlama düzeyleri arasında farklılık olup olmadığına bakılmıştır, yapılabilecek diğer araştırmalarda da Matematik ve Fen Bilimlerinde yaş farklılığ olan aynı sınıf düzeyindeki öğrencilerin başarıları arasında farklılık olup olmadığına bakılabilir.

4. $4+4+4$ eğitim sisteminin uygulandığı ilk grup öğrenciler arasında yaşı daha küçük olan öğrencilere destek programlar hazırlanmalıdır. Ayn sınıf seviyesinde olan ama aynı yaşta olmayan bu öğrenciler, aynı ölçme ve değerlendirme sürecine tabi tutulmamalılardır. Bu öğrenciler için ölçme değerlendirme sürecinde ek uygulamalara gidilmelidir. 
5. Öğrencilerin tüm derslerdeki akademik başarılarında okuduğunu anlama düzeylerinin önemli olduğu düşünülürse gerekli biyolojik olgunluğa ulaşmadan okula başlayan öğrencilerin okul hayatı boyunca yaşayacağı sıkıntılar hem velileri hem öğretmenleri hem de öğrencileri olumsuz yönde etkileyecektir. Bu sebeple 60-66 aylık çocuklar için uyum haftası hariç ek düzenlemelere gidilmeli, hatta okula başlama yaşı değiştirilmelidir.

\subsection{Araştırmacılar İçin Öneriler}

1. Bu çalışma sadece ilkokul ikinci sınıf öğrencileri üzerinde yapılmıştır. Araştırmada çıkan farklılı̆̆ın eğitim-öğretim süreci içeri- sinde kapanıp kapanmayacağını gözlemlemek için, çalışma boylamsal olarak genişletilebilir. Böylece yaşla ve cinsiyetle ilgili farklılıkların ilerleyen yıllarda değişime uğrayıp uğramayacağı gözlemlenebilir.

2. Araştırma random seçilen örneklem grubunda okul öncesi eğitim alma düzeyi çok düşük olduğu gözlemlendiği için bu araştırmanın değişkenleri arasına alınmamıştır; ancak yeni yapılacak çalışmalarda bu değişkenin önemli olacağı düşünülmektedir. Yeni araştırmalarda okul öncesi eğitim alan ve almayan öğrencilerin okuduğunu anlama düzeyleri arasında bir ilişki olup olmadığı araştırılabilir.

\section{Kaynakça}

Albayrak, A.S. (2006), Uygulamahı Çok Değişkenli İstatistik Teknikleri, Asil Yayın Dağıtım: Ankara.

Büyüköztürk, Ş. (2002). Sosyal Bilimler İçin Veri Analizi El Kitabı, Ankara: Pegem A Yayıncılık.

Cemiloğlu, M. (2001). Türkçe Öğretimi. İstanbul: İstanbul Alfa.

Çiftçi, Ö. ve Temizyürek, F. (2008). İlköğretim 5.Sınıf öğrencilerinin okuduğunu anlama becerilerinin ölçülmesi. Mustafa Kemal Üniversitesi Sosyal Bilimler Enstitüsü Dergisi, 5(9), 109-129.

Demirel, Ö. (2000). Türkçe Öğretimi. Ankara: Pegem A Yayıncllık.

Dökmen, Ü. (1994). Okuma Becerisi, İlgisi ve Alışkanlığı Üzerine Psiko-Sosyal Bir Araştırma. Ankara: MEB Yayınevi.

Eğitim-Bir-Sen. (2013). 1. Yılını dolduran 4+4+4 Ĕ̆itim Sistemine İlişkin En Kapsamlı İzleme ve Değerlendirme Çalı̧̧ması. İstanbul.

Eğitim Reformu Girişimi. (2013). 4+4+4 Düzenlemesi ile Neler Değişti? Yeni Sisteme Geçişte Neler İzlenmeli? İstanbul: Eğitim Reformu Girişimi.

Güneş, F. (2000). Uygulamalı Okuma Yazma Öğretimi. Ankara: Ocak Yayınları.

Güneş, F. (2009). Türkçe öğretiminde günümüz gelişmeleri ve yaklaşımları. Mustafa Kemal Üniversitesi Sosyal Bilimler Enstitüsü Dergisi, 6(11), 1-21.

Gürses, R. (1996, Eylül). Okuma Anlama Üzerine. Atatürk Kültür, Dil ve Tarih Yüksek Kurumu Bülteni, 9(28), 98-103.

Gündüz, F. ve Çalışkan, M. (2013). 60-66, 66-72, 72-84 aylık çocukların okul olgunluk ve okuma yazma becerilerini kazanma düzeylerinin incelenmesi, Turkish Studies International Periodical Forthe Languages, Literatureand History Of Turkish Orturkic, 8(8), 379-398

İlköğretim ve Eğitim Kanunu,. (1961). T.C. Resmi Gazete, 10705, 5 Ocak 1961.

Karasar, N. (2000). Bilimsel Araştırma Yöntemi (10.Baskı b.). Ankara: Nobel Yayın Dağıtım. 
Kavcar, C., Oğuzkan, F. ve Sever, S. (1997). Türkçe Öğretimi: Türkçe ve Sinıf Öğretmenleri İçin. Ankara: Engin Yayıncilık.

Kılıç, A., (2000). İlk Okuma Yazma Öğretiminde Programlandırılmış Öğretitatlme Göre Metin Yönteminin Etkililiği, Yayımlanmamış Yüksek Lisans Tezi, Hacettepe Üniversitesi Sosyal Bilimler Enstitüsü.

Kuşdemir Kayıran, B. ve Karabay, A. (2012, Güz). İlkokuma yazmayı farklı yöntemlerle öğrenen ilköğretim beşinci sınıf öğrencilerinin okuduğunu anlama becerileri üzerine bir çalışma. Kuram ve Uygulamada Ĕ̆itim Bilimleri, s. 2847-2860.

MEB. (2012). 12 Yıl Zorunlu Eğitim Sorular ve Cevaplar. Ankara.

Öz, F. M. ve Çelik, K. (2007). Uygulamalı İlkokuma Yazma Öğretimi. İstanbul: Anı Yayınevi

Özçelik, D. A. (1987). Eğitim Programları ve Öğretim(Genel Öğretim Yöntemi). Ankara: ÖSYM Yayınları.

Paul, R. (1995). Critical Thinking: How To Prepare Students For A Rapidly Changing World. (Cilt Appendi B). (F. F. Thinking, Dü.) Dillon Beach.

Savaş, B. (2006). Okuma Eğitimi ve Çocuklarda Dil Gelişimi. İstanbul: Alfa Basım Yayım Dağıtım.

Sidekli, S. (2010). Eylem araştırması: ilköğretim dördüncü sınıf öğrencilerinin okuma ve anlama güçlüklerinin giderilmesi. TÜBAR, s. 563-580.

Şengül , M., ve Yalçın, S. (2004, Güz). Okuma ve Anlama Becerilerinin Geliştirilmesine Yönelik Olarak Hazırlanan Bir Model Önerisi. Milli Eğitim Dergisi (164).

Tatlıdil, H., (2002). Uygulamalı Çok Değişkenli İstatistiksel Analiz, Ziraat Matbaacılık: Ankara.

Tok, Ş., Tok, T. N. ve Mazı, A. (2008). İlkokuma yazma öğretiminde çözümleme ve ses temelli cümle yönteminin değerlendirilmesi. Kuram ve Uygulamada Ĕ̆itim Yönetimi(55), 123-144.

Yılmaz, M. (2008). Türkçe'de okuduğunu anlama becerilerini geliştirme yolları. Mustafa Kemal Üniversitesi Sosyal Bilimler Enstitüsü Dergisi, 5(9), 131-139. 


\section{Extended Summary}

Changes in the educational system have affected primary students the most since the academic year 2012-2013, the year when compulsory education of twelve years was first implemented in the history of Republic of Turkey. A good number of changes were brought along to the system by $4+4+4$ education system. After the law amendment being published in the Official Gazette on July $21^{\text {st }}$, 2012, it came into force. The regulation was adjusted as follows: "Children who complete 66 months as of 30 September of the year in question will be enrolled to primary education and 60-66 month old children whose parents submit an official written request on their developmental readiness for primary school can start primary education. As for children who turn 66 months or over and legally entitled to primary education but are not psychically and mentally ready thus cannot comply with school surrounding, they can be referred to pre-primary education or their school can be postponed for a year upon submission of a relevant medical report given by health institutions until the end of November (Ministry of National Education, 2012).

All the changes brought by " $4+4+4$ " system have affected those students who started the first grade at primary school in the academic year 2012-201 the most. Attempts were made to make a gradual transition into this new program and students at each grade were not simultaneously subjected to change. Instead, a gradual transition was targeted starting with the first graders.

The first grade is of critical importance as it is the first environment where a student is to acquire reading comprehension skills. To this end, the first grade of the primary school as the basic educational establishment is regarded as the most crucial step to help students gain reading comprehension skills. The process initiated by literacy is accompanied by the acquisition of reading comprehension skills.

Reading in its essence is the process of perceiving printed or written texts through our sensory organs, making meaning and interpreting (Gürses, 1996). The act of reading is a physiological process as it involves seeing and vocalizing and it is psychological due to incorporation of comprehension and lastly a sociological one as it is about sense-making. In this respect, its development might vary depending on biological differences as well as individual and environmental ones (Kayran and Karabay, 2012).

Reading has been regarded as one of the most efficient ways of acquisition and spread of knowledge since the first ages (Güneş, 2000). Learning, however, takes place through text-reading in modern societies (Savaş, 2006).

As literacy skills are significant and essential skills for learning, it is vital to teach them in primary school (Şengül and Yalçın, 2004). Usually starting with being familiar with letters and followed by vocalizing in the first grade, literacy skills folds its importance by incorporating comprehension in upper grades. The aim of this study is to compare the second graders' reading comprehension skills in terms of age and gender. To this end, the following questions were asked:

1. Is there any statistically significant difference in terms of success in reading comprehension in Turkish lesson among 72-78 months, 79-85 months and 86-92 months old students?

2. Does the success in reading comprehension in Turkish lesson of the second graders at different ages differ depending on gender? 
This study is a descriptive one which was conducted through single screening model, one of the screening models. Screening model is the approach aimed to describe a current or past condition in the way it is or it was (Karasar, 2000).

Population of the study comprises of the second grade students in Istanbul in the second semester of the academic year 2013-2014. As for the study sample, 156 second graders in two primary schools on European side of Istanbul were randomly chosen.

A pool of 500 questions was prepared for data collection purposes. 3 independent experts were consulted to eliminate some of these questions. Remaining questions were analyzed and redundant and internally similar items were omitted. Eventually, Test of Reading Comprehension for the 2nd Grade was created and it was examined by an expert linguist and a specialist in education. After the necessary adjustments, the test was administered to both the third graders who completed this lesson successfully and the first graders that never took it. Test results were used to determine item difficulty and discrimination index of each item. Items with a discrimination index lower than 0.20 were eliminated and the test finalized.

In data collection process, the aforementioned test was given to teachers working with the second graders and they were asked to administer it. Students' chronological age was taken into consideration while groups were being created. Each group was given "Test of Reading Comprehension for the 2nd Grade" and results were analyzed by SPSS 20.00 .

In data analysis process, Kruskal-Wallis analysis was used to determine whether there are differences among independent age groups in terms of average success or not. Moreover, Mann-Whitney U test was administered to see whether success vary according to gender or not.

Results of the analysis indicate that there is a statistically significant difference in favor of the students in the third group (86-92 months old). The finding, $x^{2}(\mathrm{df}=2, \mathrm{n}=156)=27.748, .00<.0 .5$, shows that students, of the same grade, who started the school in later months in terms of age groups were found to have better reading comprehension skills.

Results of the analysis of the scores that male and female students obtained from "Turkish Test of Reading Comprehension" conducted by Mann Whitney U-test were presented in Table 1.2. They point to a statistically significant difference in favor of female students. When $U=2429,500$ p $<.0 .5$ averages are considered, it is understood that female students outperform male students in reading comprehension skills.

Studies show that reading comprehension skills vary depending on age groups in the second grade of the primary school. When such difference is analyzed, 86-92-month-old students in the third group, that is to say older ones, were observed to be more successful in reading comprehension. The reason why students who have been taught in the same class for two years obtain such different test results could be attributed to the difference between their readiness levels.

We have arrived at the following results as a result of the findings and relevant interpretations: Educational system should be diversified in such a manner that needs of the students who are younger than others and go to the same grade are taken into consideration. As differences between literacy skills of the students with different ages have an impact on their overall success in the lesson, instruction provided for younger ones are to be diversified. It is vital if the aim is to help all students to attain the same 
level of acquisition. The aim of this study is to determine whether age is a determinant of reading comprehension skills or not for the second graders. As families decide on when students are enrolled into schools, it is essential to raise their awareness of this issue. Study sample included students with different characteristics. It can still be recommended that the study be duplicated by extending the study sample.

The following recommendations are presented in line with the results: educational system should be diversified taking the needs of the younger second graders into consideration. Students in lower age groups should be given instruction in different classes. Studies should be conducted to examine differences in needs and skills of the first grade students who both had pre-primary education and who did not do so. In addition, physical conditions of schools should be investigated to find out whether they are convenient for student in lower age groups. This study should be duplicated by extending the sample. 